\section{Characterization of Trophic Transfer for Polychlorinated Dibenzo-p-dioxins, Dibenzofurans, Non- and Mono-ortho Polychlorinated Biphenyls in the Marine Food Web of Bohai Bay, North China}

YI WAN, ${ }^{\dagger}$ JIANYING HU, ${ }^{*},+$ MIN YANG, LIHUI AN, ${ }^{\dagger}$, WEI AN, ${ }^{\dagger}$ XIAOHUI JIN,

TATSUYA HATTORI, $\$$ AND

M I T S U A K I I T O H $\$$

College of Environmental Science, Beijing University, Beijing 100871, China, State Key Lab of Environmental Aquatic Chemistry, Research Center for Eco-Environmental Sciences, Chinese Academy of Sciences, Beijing 100085, China, and Research Center for Environmental Risk, Institute of Environmental Ecology, Metocean Environment Inc., Shizuoka 421-0212, Japan

Many investigations have highlighted the bioaccumulation of dioxins in animals, but little is known about the trophodynamics of dioxins in the food web. In this study, the trophic transfer of nine dibenzo- $p$-dioxin (PCDD) congeners, eleven dibenzofuran (PCDF) congeners, and twelve non-, mono-ortho polychlorinated biphenyl (non- and mono-ortho PCBs) congeners in a marine food web were determined. The concentrations of PCDDs, PCDFs, non- and mono-ortho PCBs were analyzed in phytoplankton/ seston, zooplankton, three invertebrate species, six fish species, and one seabirds species collected from Bohai Bay, representing approximately 4 trophic levels based on stable nitrogen isotope values. Positive relationships were found between trophic levels and lipid equivalent concentrations of non- and mono-ortho PCBs except for PCB77, PCB-81, PCB-126, PCB-156, and PCB-167, indicating bioaccumulation of these compounds in this food web. But lipid equivalent concentrations of low chlorinated 2,3,7,8substituted-PCDD/Fs did not exhibit statistically significant trends with trophic levels. And lipid equivalent concentrations of high chlorinated 2,3,7,8-substituted-PCDD/Fs and three non-2,3,7,8-substituted-PCDD/Fs declined significantly with increasing trophic levels providing that these isomers undergo trophic dilution. The similarity in $\log K_{\text {ow }}$ values for non-, mono-ortho PCBs, non-2,3,7,8-substitutedPCDD/Fs, and some 2,3,7,8-substituted-PCDD/Fs suggests that the difference of trophic transfer is mainly due to their different metabolic transformation rates.

\footnotetext{
${ }^{*}$ Corresponding author phone and fax: 86-10-62765520; e-mail: hujy@urban.pku.edu.cn.

${ }^{\dagger}$ Beijing University.

Chinese Academy of Sciences.

${ }^{\S}$ Metocean Environment Inc.
}

\section{Introduction}

Planar halogenated aromatic hydrocarbons (PHAHs) such as polychlorinated dibenzo- $p$-dioxins (PCDDs), dibenzofurans (PCDFs), non- and mono-ortho polychlorinated biphenyls (non- and mono-ortho PCBs) are of great concern because their toxicity included hormone-dependent cancers and reproductive effects in humans and wildlife (1), and these pollutants are ubiquitous in different environmental media $(2-5)$. Being highly lipophilic and resistant toward metabolic breakdown, PCDDs, PCDFs, non- and mono-ortho PCBs can accumulate in predators at the top of a food chain (6), causing potential risk to high trophic level wildlife.

Because dietary uptake is the major route of dioxin exposure in humans, numerous studies have been conducted to determine the occurrence of dioxin in fish and other aquatic organisms from freshwater and marine environments $(1,5,7)$. Recently, many studies have focused on high trophic level animals such as seabirds, cetaceans, and seals, using them as bioindicators for monitoring marine pollution ( 6 , $8-12$ ). In addition to the studies on the accumulation of dioxin in high trophic level animals, biomagnification in the food web has also been described $(4,13)$ by using stable isotopes of nitrogen to provide continuous trophic levels, a method which has been used to study the dynamics of polychlorinated biphenyls (PCBs) and organochlorine contaminants in marine and freshwater food webs $(14-18)$. Naito (4) studied the tropodynamics of PCDDs, PCDFs, non- and mono-ortho PCBs in the aquatic food chain of Tokyo Bay and found that non- and mono-ortho PCBs have a significantly higher biomagnification potential than PCDD/Fs. However, the food web used in Naito's study excluded organisms such as seabirds or mammals at high trophic levels, which are often included in the trophodynamic studies of chemicals $(14,17,19,20)$. On the other hand, Broman (13) focused on the estimation of the bioaccumulation of PCDD/ Fs in two marine food webs including phytoplankton, zooplankton, fish, and eider ducks from the Northern Baltic. While the fate of PCDD/Fs was found to be similar to that reported by Naito (4), non- and mono-ortho PCBs were not included in the investigation. Moreover, in the biomagnification calculation of dioxin, both works used concentrations (wet weight) which were not corrected by lipids, although some works found a 1.5-fold increase in lipid with increasing trophic levels accounting in part for higher persistent organic pollutants (POPs) concentrations in upper trophic level organisms (21).

Bohai Bay is an enclosed inner sea in north China, and as the area is highly developed economically, about 1 billion tons of wastewater were discharged into the bay from Beijing, Tianjin, and Hebei province every year, causing great risk to the marine ecology. The present study analyzed nine PCDDs, eleven PCDF isomers, and twelve non-, mono-ortho PCB congeners in samples of phytoplankton/seston, zooplankton, three invertebrate species, six fish species, and one marine bird, and stable isotope analysis of nitrogen was used to quantitatively determine the trophic levels of these organisms. Hexachlorobenzene (HCB) was used as a benchmark for trophic transfer of dioxin. Concentrations for biomagnification calculation are expressed in terms of lipid equivalent concentrations, so that the contribution of contaminant concentrations from lipid to biomagnifications of PCDDs, PCDFs, nonand mono-ortho PCBs can be disregarded. As the first survey of PCDDs, PCDFs, non- and mono-ortho 
PCBs in the marine food web in Bohai Bay, this study presents the characterization of trophic transfer for these pollutants.

\section{Materials and Methods}

Sample Collection. Bohai Bay is an isolated inner sea located in the northeast region of China with an area of about 80000 $\mathrm{km}^{2}$ and an average depth of about $18 \mathrm{~m}$. Aquatic food web components excluding seabirds in Bohai Bay were collected in May, June, and September 2002 (39 $12^{\prime}$ N, 117 $59^{\prime}$ E). Seabirds were collected in November 2002 on the coast of the bay $\left(39^{\circ} 07^{\prime} \mathrm{N}, 117^{\circ} 44^{\prime} \mathrm{E}\right)$. The part of the marine food web for study included primary producers (phytoplankton/ seston and zooplankton), three invertebrate species (crab (Portunus trituberculatus), burrowing shrimp (Upogebia sp.), and bay scallop (Argopecten irradians)), six fish species (weever (Lateolabras japonicus), catfish (Chaeturichthys sitgmatias), bartail flathead (Platycephalus indicus), white flower croaker (Nibea albiflora), and mullet (Liza so-iuy)), and one seabird species (herring gull (Larus argentatus)). Phytoplankton/seston and zooplankton were obtained from vertical tows (bottom to surface) using $31.6 \mathrm{~cm}$ i.d. $\times 140 \mathrm{~m}$ long nets $(77-\mu \mathrm{m}$ mesh) and $37 \mathrm{~cm}$ i.d. $\times 140 \mathrm{~m}$ long nets (160- $\mu \mathrm{m}$ mesh), respectively, from six locations $\left(39^{\circ} 00^{\prime} \mathrm{N}\right.$, $117^{\circ} 53^{\prime} \mathrm{E} ; 39^{\circ} 00^{\prime} \mathrm{N}, 118^{\circ} 00^{\prime} \mathrm{E} ; 38^{\circ} 45^{\prime} \mathrm{N}, 117^{\circ} 53^{\prime} \mathrm{E} ; 38^{\circ} 45^{\prime} \mathrm{N}$, $118^{\circ} 00^{\prime} \mathrm{E} ; 38^{\circ} 30^{\prime} \mathrm{N}, 117^{\circ} 53^{\prime} \mathrm{E}$; and $\left.38^{\circ} 30^{\prime} \mathrm{N}, 118^{\circ} 00^{\prime} \mathrm{E}\right)$. The phytoplankton/seston samples mainly consisted of algae of the taxonomic groups Bacillariophyta and Pyrrophyta, and the samples of zooplankton mainly consisted of small copepods (Acartia bifilosa, Paracalanus parvus, Labidocera euchaeta, and Oithona similes), which are primary herbivores. Invertebrates and fishes were caught with a bottom trawl, and Seabirds were captured before their winter migration commenced. All samples were stored at $-20{ }^{\circ} \mathrm{C}$ prior to analysis.

Chemical Analysis. Isotopic and HCB analyses were made on three of the phytoplankton/seston and zooplankton samples from six locations, and dioxin analysis was made on a pooled sample. Isotopic and HCB analyses of invertebrates and fishes were made on three individuals for each species and dioxin analysis was made on a pooled sample. For seabird samples isotopic, HCB, and dioxin analyses were both made on four individuals. Dioxin analysis was conducted following the method reported by the Environmental Agency of Japan with some modifications (22) and a detailed description is provided in the Supporting Information. The instrumental conditions of dioxin analysis, the analytical method of HCB, stable nitrogen isotope analysis, the quantitation and quality assurance/quality control (QA/QC), and lipid content analysis of samples are also provided in the Supporting Information.

Trophic Level Calculation. Trophic levels of individual aquatic organisms can be calculated using the following relationship given by Fisk et al. (14) and Muir et al. (18):

$$
\mathrm{TL}_{\text {consumer }}=2+\left(\delta^{15} \mathrm{~N}_{\text {consumer }}-\delta^{15} \mathrm{~N}_{\text {zooplankton }}\right) / 3.8
$$

where $\delta^{15} \mathrm{~N}_{\text {consumer }}$ and $\delta^{15} \mathrm{~N}_{\text {zooplankton }}$ are stable nitrogen isotope values of consumer and zooplankton, $\mathrm{TL}_{\text {consumer }}$ is the trophic level of consumers, and the TL of zooplankton was assumed to be 2. But for the calculation of trophic level in birds, the diet-tissue isotope fractionation factor is $+2.4 \%$ ond the equation should be modified to the following (14):

$$
\mathrm{TL}_{\text {bird }}=3+\left(\delta^{15} \mathrm{~N}_{\text {bird }}-2.4-\delta^{15} \mathrm{~N}_{\text {zooplankton }}\right) / 3.8
$$

where $\mathrm{TL}_{\mathrm{bird}}$ is the trophic level of bird and $\delta^{15} \mathrm{~N}_{\text {bird }}$ is the stable nitrogen isotope value of birds. Because trophic magnification factors (TMFs) represent an average rate of increase per trophic level rather than specific predato-prey relationships (19), we used it to describe the food web biomagnification of the chemicals. The factors are based on the relationships between the trophic level and the dioxin concentration using simple linear regression

Log dioxin concentration (lipid corrected) $=a+b \times$

The concentrations below the detection limit were treated as half of the detection limit (Table 1). The $b$ in eq 3 was used to calculate TMF, which is the same factor with food web magnification factor (FWMF), by the following equation

$$
\mathrm{TMF}=10^{b}
$$

Correlations between dioxin concentrations and trophic levels were examined by Spearman's rank correlation test, and when the value of $p$ was below 0.05 , the linear regression between dioxin concentration and trophic level were regarded as significant.

\section{Results and Discussion}

Trophic Levels of Organisms in the Marine Food Web from Bohai Bay. The $\delta^{15} \mathrm{~N}$ in the marine food web of Bohai Bay ranged widely from 4.08 to $14.60 \%$. The trophic levels for all organisms were converted from $\delta^{15} \mathrm{~N}$ values according to eqs 1 and 2, and the results are shown in Table 1. The trophic level of phytoplankton/seston sample averaged 1.61. This value is located between the trophic levels of plankton (1.05) and seston (1.84), which were converted from $\delta^{15} \mathrm{~N}$ values reported previously (13) according to eq 1 . Trophic levels of fish species varied from 3.01 to 3.88, which is similar to those (3.0-4.1) estimated by traditional stomach content analysis (23). The trophic levels for invertebrates ranged from 2.15 to 3.16 , which can be safely explained by the fact that invertebrates primarily eating planktons were classified between zooplankton and fish species. The trophic level of seabirds was 4.06 , which was classified as the top predator among the biological samples in this study.

PCDD, PCDF, Non- and Mono-ortho PCB residues and TEQs. Concentrations of 9 PCDD and 11 PCDF congeners detected in organisms of the food web are given in Table 1, and the total PCDD/F concentrations ranged from 7.6 (wolfish (Obontamblyopus rubicundus)) to $36 \mathrm{pg} / \mathrm{g}$ wet weight (herring gull (Larus argentatus)). Concentrations of PCDD/Fs in organisms in Bohai Bay were comparable to those in biological samples from a Japanese freshwater lake (24), but much lower than the concentrations in fish samples collected from Tokyo Bay (4) and from a heavily polluted lake in China (5), and in bird (herring gull (Larus argentatus)) samples from Lake Michigan (10). This corresponds to the low PCDD/F concentrations in sediment samples in Bohai Bay (25). The results in Figure 1 indicate that the concentrations of congeners with a high degree of chlorination decreased with an increase in trophic level, and concentrations of congeners with a low degree of chlorination increased with an increase in trophic level. These results were similar to those reported by Naito (4). Thus, OCDD and H7CDD (OCDD, 22-68\%; H7CDD, 9-22\%) were two major congeners among the $\mathrm{PCDD} / \mathrm{F}$ congeners in all samples, which corresponds with the pattern of PCDD/Fs in sediment in Bohai Bay (25).

Total concentrations of non- and mono-ortho PCBs ranged from 0.73 to $1100 \mathrm{pg} / \mathrm{g}$ wet weight and from 5.2 to $12000 \mathrm{pg} / \mathrm{g}$ wet weight, respectively (Table 1). The highest concentration of total non- and mono-ortho PCBs was found in herring gulls (Larus argentatus) (2800-13 000 pg/g wet weight); however, this concentration was still lower than those found in fish samples collected in Tokyo Bay (4). Greater than $87 \%$ of the concentrations of non- and mono-ortho PCBs were contributed by mono-ortho PCBs, and CB-118 was the predominant congener $(53-65 \%)$ among monoortho PCB congeners in all organisms detected, followed by 


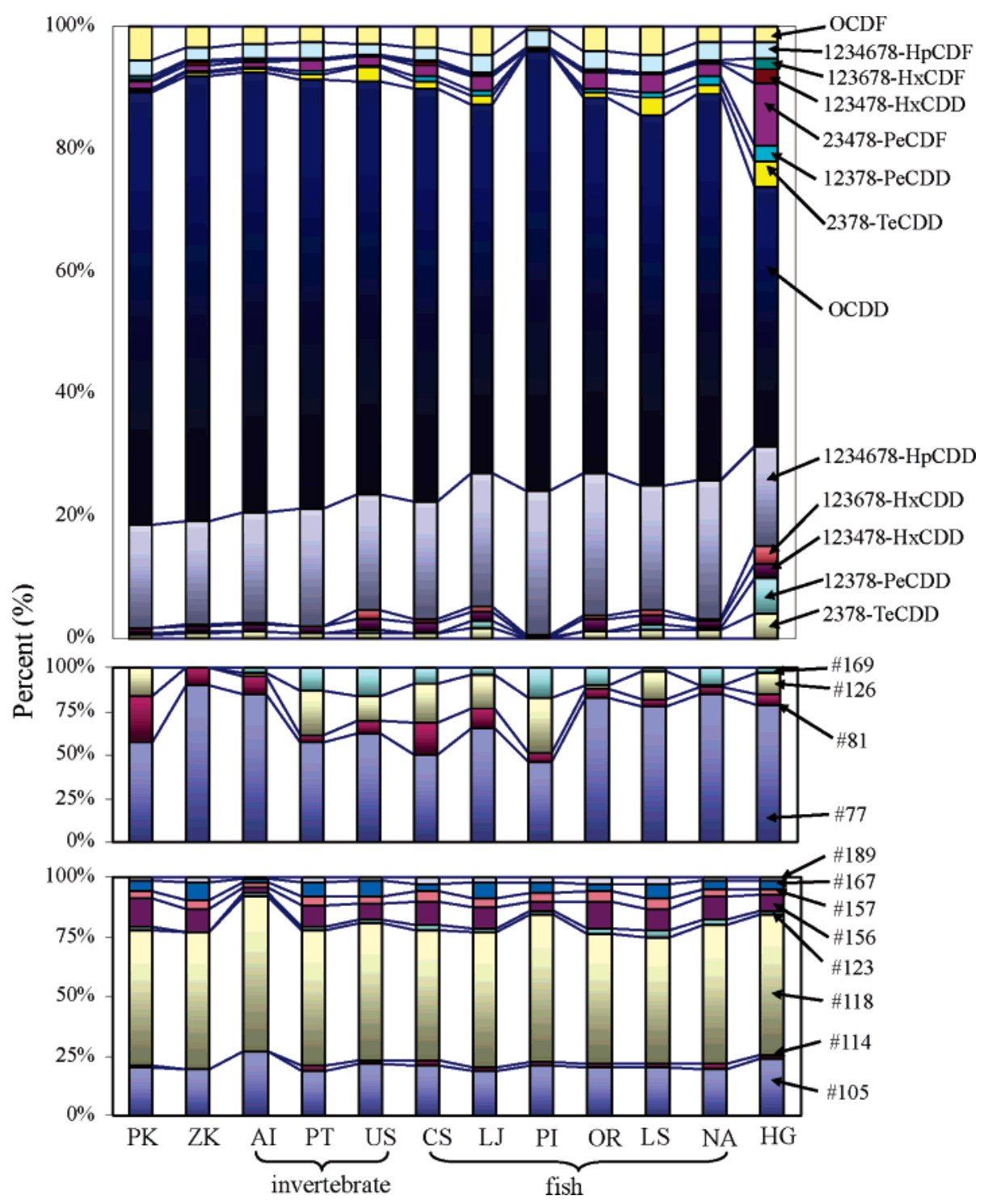

FIGURE 1. Percentage contribution of congeners to total PCDD/Fs, non- and mono-ortho PCBs in organisms detected. The PCDD/F congeners with low percent are not shown: PK = phytoplankton/seston; ZK = zooplankton; AI = bay scallop (Argopecten irradians); PT = crab (Portunus trituberculatus); US = burrowing shrimp (Upogebia sp.); CS = catfish (Chaeturichthys sitgmatias); LJ = weever (Lateolabras japonicus); $\mathrm{PI}=$ bartail flathead (Platycephalus indicus); $\mathbf{O R}=$ wolffish (Obontamblyopus rubicundus); LS = mullet (Liza so-iuy); NA = white flower croaker (Nibea albiflora); HG = herring gull (Larus argentatus).

CB-105 (19-27\%), CB-156 (2-12\%), and CB-167 (2-8\%). The congener patterns of mono-ortho PCBs were found to be similar to those found in different biological species from different areas $(1,4,11,12,26)$. On the other hand, the congener patterns of nonortho PCBs in organisms detected were not constant, and PCB-77 was the predominant congener accounting for between $46 \%$ in bartail flathead and $89 \%$ in bay scallop, which was similar only to the results reported by Naito (4), perhaps because of the similarity of the two marine environments. It should be noted that the mean concentration ratio of PCDD/Fs to non- and monoortho PCBs is significantly higher in sediment (16.2, ref 25) than in organisms $(0.01-2.1)$ in Bohai Bay, suggesting that the biota-sediment accumulation factors of PCDD/Fs would be lower than those of non- and mono-ortho PCBs.

The toxic equivalency (TEQ) of PCDDs, PCDFs, non- and mono-ortho PCBs in aquatic organisms and seabirds were calculated from fish and bird toxic equivalency factors (TEFs), respectively, which were reported by the World Health Organization (27). Concentrations of TEQs in all organisms ranged from 0.06 to $65 \mathrm{pg} / \mathrm{g}$ wet weight, and birds showed the highest concentrations of TEQs, which ranged from 12 to $65 \mathrm{pg} / \mathrm{g}$ wet weight. In aquatic organisms excluding birds, more than $85 \%$ of TEQs was contributed by PCDD/Fs; however, in bird samples, the $60-93 \%$ of TEQs were mainly contributed by non- and mono-ortho PCBs, especially by nonortho PCBs (Supporting Information Figure 1). These phenomena are also supported by many references $(1,10$, $11,26,28,29)$. In all aquatic organisms, 2,3,7,8-TeCDD, 1,2,3,7,8-PeCDD, 1,2,3,4,7,8-HxCDD, and 2,3,4,7,8-PeCDF were the four congeners with the highest TEQ contributions to total PCDD/Fs, accounting for $20-48 \%$, 3-23\%, 14-27\%, and $10-34 \%$, respectively. In addition, in bird samples, the TEQ contribution of $1,2,3,4,7,8$-HxCDD decreased to $0.3-$ $0.5 \%$, while $2,3,4,7,8$-PeCDF become another major TEQcontributing congener, accounting for $18-48 \%$ of the total $\mathrm{PCDD} / \mathrm{Fs}$.

Trophodynamics. Concentrations of HCB in organisms are shown in Supporting Information. A statistic significant regression was obtained between logarithmic concentrations (lipid-corrected) of HCB and trophic levels, and the TMF was estimated to be 2.96 ( $p=0.001$ ) indicating that HCB is subject to biomagnification in the food web (Figure 2). This result is supported by evidence from the literature $(14,18-$ 


\begin{tabular}{|c|c|c|c|c|c|c|c|c|c|c|c|c|}
\hline & PKS $^{b}$ & ZK & Al & PT & US & cs & LJ & PI & OR & LS & NA & HG \\
\hline trophic level & $\begin{array}{c}1.61 \\
(1.46-1.74)\end{array}$ & $\begin{array}{c}2.00 \\
(1.85-2.10)\end{array}$ & $\begin{array}{c}2.15 \\
(1.91-2.31)\end{array}$ & $\begin{array}{c}3.10 \\
(2.96-3.29)\end{array}$ & $\begin{array}{c}3.16 \\
(3.06-3.32)\end{array}$ & $\begin{array}{c}3.67 \\
(3.64-3.71)\end{array}$ & $\begin{array}{c}3.88 \\
(3.53-4.23)\end{array}$ & $\begin{array}{c}3.65 \\
(3.42-3.90)\end{array}$ & $\begin{array}{c}3.58 \\
(3.45-3.64)\end{array}$ & $\begin{array}{c}3.01 \\
(2.55-3.43)\end{array}$ & $\begin{array}{c}3.59 \\
(3.30-4.06)\end{array}$ & $\begin{array}{c}4.06 \\
(3.58-4.28)\end{array}$ \\
\hline $\begin{array}{l}\text { no. samples in pool } \\
\text { length }(\mathrm{cm})\end{array}$ & & & $8^{2.011}$ & 6 & 6 & $\begin{array}{c}3 \\
20 \\
(19-22)\end{array}$ & $\begin{array}{c}2 \\
35 \\
(22-48)\end{array}$ & $\begin{array}{c}3 \\
38 \\
(24-61)\end{array}$ & $\begin{array}{c}3 \\
32 \\
(30-34)\end{array}$ & $\begin{array}{c}3 \\
20 \\
(19-21)\end{array}$ & $\begin{array}{c}3 \\
23 \\
(19-32)\end{array}$ & $\begin{array}{c}4^{c} \\
35.6 \\
(31-41)\end{array}$ \\
\hline weight (g) & & & & & & $\begin{array}{c}88 \\
(78-102)\end{array}$ & $\begin{array}{c}728 \\
(180-1276)\end{array}$ & $\begin{array}{c}445 \\
(95-1119)\end{array}$ & $\begin{array}{c}29 \\
(25-32)\end{array}$ & $\begin{array}{c}91 \\
(86-95)\end{array}$ & $\begin{array}{c}222 \\
(58-538)\end{array}$ & $\begin{array}{c}208 \\
(142-321)\end{array}$ \\
\hline lipid (\%) & 2.2 & 1.8 & 6.4 & 5.3 & 13.6 & $\begin{array}{c}4.8 \\
(4.4-5.1)\end{array}$ & $\begin{array}{c}4.7 \\
(4.6-4.7)\end{array}$ & $\begin{array}{c}2.6 \\
(2.0-3.6)\end{array}$ & $\begin{array}{c}3.1 \\
(2.3-4.1)\end{array}$ & $\begin{array}{c}4.0 \\
(3.2-4.8)\end{array}$ & $\begin{array}{c}2.6 \\
(1.1-3.4)\end{array}$ & $\begin{array}{c}9.47 \\
(6.13-16.61)\end{array}$ \\
\hline 1,3,6,8-TeCDD & 0.24 & 0.24 & 0.14 & 0.20 & 0.80 & 0.04 & 0.04 & 0.22 & 0.03 & 0.05 & N.D. & $\begin{array}{c}0.1 \\
(0.06-0.13)\end{array}$ \\
\hline 1,3,7,9-TeCDD & 0.14 & 0.11 & 0.08 & 0.08 & 0.75 & N.D. & N.D. & N.D. & N.D. & 0.03 & N.D. & $\begin{array}{c}0.01 \\
\text { (N.D. }-9.95)\end{array}$ \\
\hline 2,3,7,8-TeCDD & 0.17 & 0.11 & 0.12 & 0.09 & 0.19 & 0.08 & 0.16 & N.D. & 0.08 & 0.12 & 0.11 & $\begin{array}{c}0.85 \\
(0.61-1.50)\end{array}$ \\
\hline TeCDDs & 0.54 & 0.67 & 0.40 & 0.49 & 2.40 & 0.12 & 0.20 & 0.22 & 0.11 & 0.20 & 0.11 & $\begin{array}{c}0.98 \\
(0.74-1.60)\end{array}$ \\
\hline 1,2,3,7,8-PeCDD & 0.07 & 0.05 & N.D. & N.D. & 0.14 & N.D. & 0.10 & N.D. & N.D. & 0.07 & N.D. & $\begin{array}{c}1.16 \\
(0.64-2.40)\end{array}$ \\
\hline PeCDDs & 0.34 & 0.42 & 0.01 & 0.10 & 2.10 & 0.01 & 0.10 & 0.01 & 0.01 & 0.07 & 0.01 & $\begin{array}{c}1.16 \\
(0.64-2.40)\end{array}$ \\
\hline $1,2,3,4,7,8-\mathrm{HxCDD}$ & 0.19 & 0.12 & 0.11 & 0.13 & 0.33 & 0.13 & 0.13 & N.D. & 0.15 & 0.14 & 0.10 & $\begin{array}{c}0.44 \\
(0.31-0.59)\end{array}$ \\
\hline $1,2,3,6,7,8-\mathrm{HxCDD}$ & N.D. & 0.05 & N.D. & N.D. & 0.29 & 0.06 & 0.08 & N.D. & 0.04 & 0.07 & N.D. & $\begin{array}{c}0.64 \\
(0.41-0.98)\end{array}$ \\
\hline 1,2,3,7,8,9-HxCDD & 0.07 & 0.05 & N.D. & N.D. & 0.15 & N.D. & 0.05 & N.D. & N.D. & N.D. & N.D. & $\begin{array}{c}0.15 \\
(0.11-0.24)\end{array}$ \\
\hline $\mathrm{HxCDDs}$ & 0.75 & 0.68 & 0.16 & 0.39 & 3.00 & 0.19 & 0.26 & 0.02 & 0.24 & 0.26 & 0.22 & $\begin{array}{c}1.47 \\
(0.98-1.80)\end{array}$ \\
\hline 1,2,3,4,6,7,8-HpCDD & 4.08 & 2.30 & 1.90 & 2.20 & 3.90 & 1.70 & 1.90 & 2.20 & 1.70 & 1.70 & 1.70 & $\begin{array}{c}3.25 \\
(3.10-3.50)\end{array}$ \\
\hline HpCDDs & 4.59 & 2.60 & 1.90 & 2.30 & 4.40 & 1.80 & 1.90 & 2.20 & 1.80 & 1.80 & 1.80 & $\begin{array}{c}3.35 \\
(3.20-3.79)\end{array}$ \\
\hline OCDD & 17 & 10 & 7.50 & 8.10 & 14 & 6 & 5.30 & 6.70 & 4.50 & 5.10 & 4.70 & $\begin{array}{c}8.63 \\
(8-10)\end{array}$ \\
\hline total PCDDs & 23.8 & 14 & 10 & 11 & 26 & 8.1 & 7.8 & 9.1 & 6.7 & 7.4 & 6.8 & $\begin{array}{c}16 \\
(14-18)\end{array}$ \\
\hline $1,2,7,8-\mathrm{TeCDF}$ & 0.08 & 0.05 & 0.09 & 0.09 & 0.41 & N.D. & N.D. & N.D. & N.D. & 0.04 & 0.03 & $\begin{array}{c}0.04 \\
\text { (N.D. }-0.06)\end{array}$ \\
\hline 2,3,7,8-TeCDF & 0.07 & 0.09 & 0.07 & 0.11 & 0.45 & 0.09 & 0.14 & N.D. & 0.06 & 0.24 & 0.11 & $\begin{array}{c}0.85 \\
(0.16-1.20)\end{array}$ \\
\hline TeCDFs & 1.24 & 1.50 & 1.10 & 2.00 & 8.50 & 0.26 & 0.30 & 0.48 & 0.09 & 1.30 & 0.41 & $\begin{array}{c}6.1 \\
(3.40-9.50)\end{array}$ \\
\hline 1,2,3,7,8-PeCDF & 0.07 & 0.04 & 0.03 & 0.06 & 0.06 & 0.07 & 0.08 & N.D. & 0.06 & 0.09 & 0.11 & $\begin{array}{c}0.53 \\
(0.24-0.70)\end{array}$ \\
\hline 2,3,4,7,8-PeCDF & 0.24 & 0.13 & 0.09 & 0.20 & 0.31 & 0.15 & 0.20 & N.D. & 0.18 & 0.23 & 0.15 & $\begin{array}{c}2.03 \\
(0.93-2.50)\end{array}$ \\
\hline
\end{tabular}




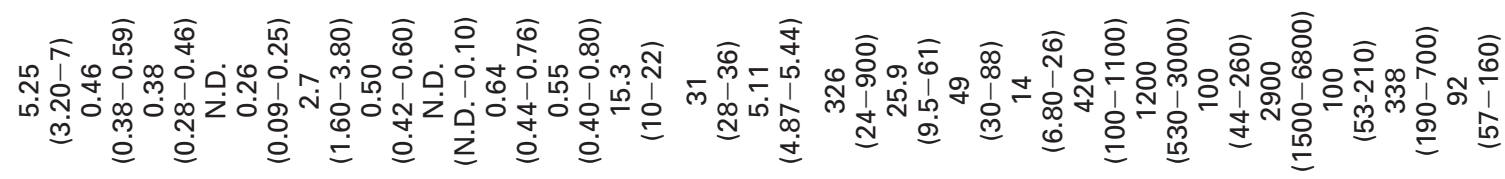

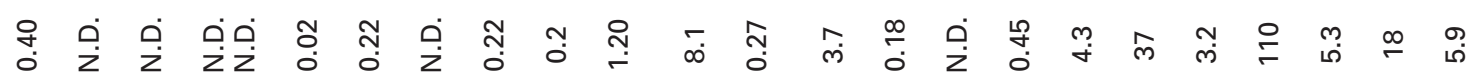

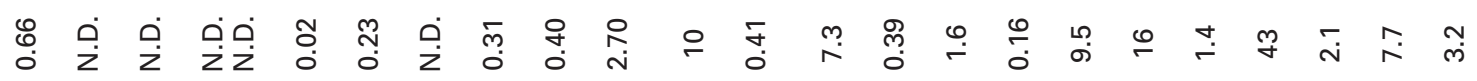

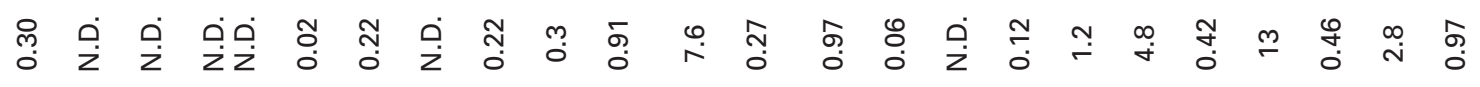

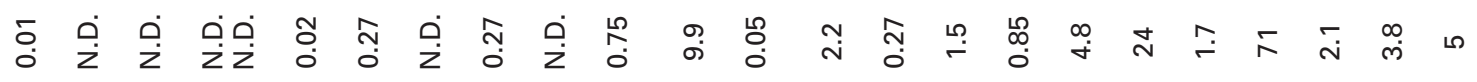

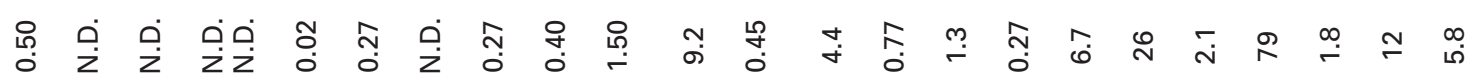

$$
\begin{aligned}
& \text { 苛 }
\end{aligned}
$$

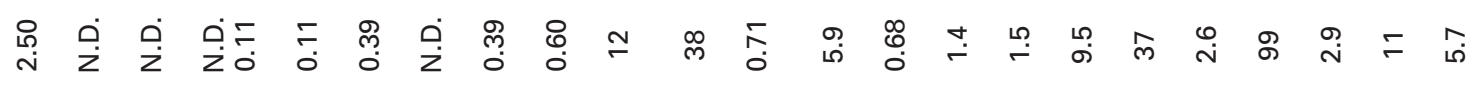

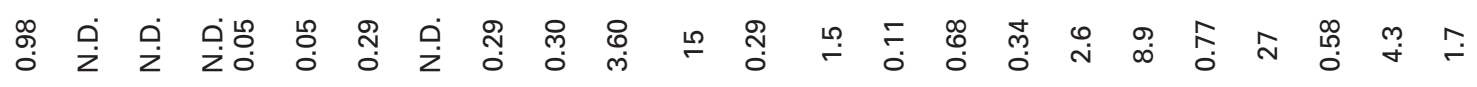

$$
\begin{aligned}
& \text { ホ⿱ } \\
& \text { 苛 }
\end{aligned}
$$

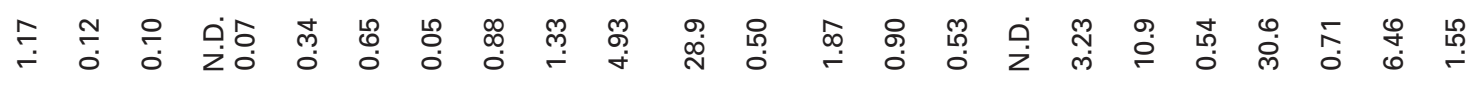

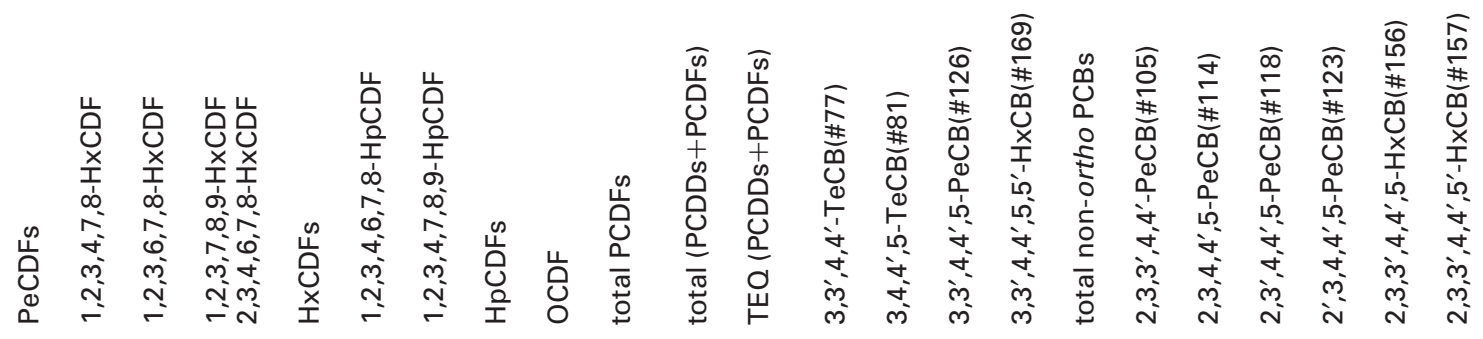




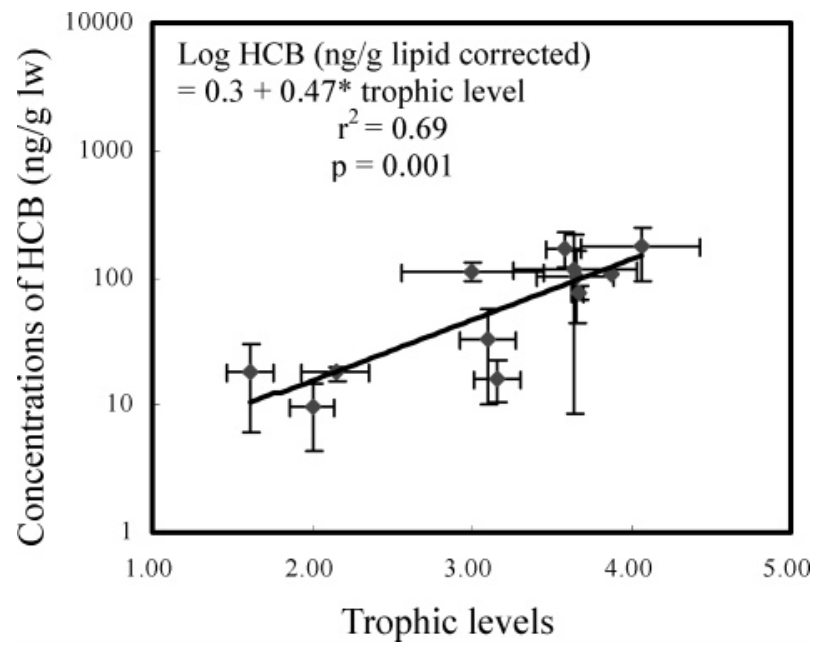

FIGURE 2. Relationship between log-transformed concentrations for HCB $(\mathrm{ng} / \mathrm{g}$, lipid corrected) and trophic levels. Mean $( \pm S D)$ values for each species are provided and trophic levels are based on $\delta^{15} \mathrm{~N}$.

20). The observed biomagnification of HCB in this food web supports that the food web studied is appropriate to test the trophodynamics of PCDD/Fs, non- and mono-ortho PCBs. The samples for dioxin analysis were pooled by the same biota (except for seabirds) as those used to analyze HCB.

Regression analysis was also conducted to investigate the relationships between logarithmic concentrations (lipidcorrected) of PCDD, PCDF, non- and mono-ortho PCB congeners and trophic levels as shown in Figure 3, and statistical results of the regression analysis are listed in Table 2. Lipid equivalent concentrations of eleven non- and monoortho PCBs in organisms increased significantly with increasing trophic level as exemplified by the results for PCB105, PCB-169, PCB-118, and PCB-189 shown in Figure 3a and $\mathrm{b}$ ( $p<0.05$ except for PCB-77, PCB-81, PCB-126, PCB156, and PCB-167), indicating that these non- and monoortho PCBs had a higher biomagnification potential than did PCDD/Fs. TMFs ranged from 3.40 for CB- 105 to 12.26 for CB-169, and increased with increasing chlorination degree from tetra- to hepta-CBs. To our knowledge, the TMFs for all twelve non- and mono-ortho PCBs have only been reported in Naito's study of the marine food web from Tokyo Bay, and in that study the TMFs of non- and mono-ortho PCBs ranged from 1.70 to 2.34 (4). Although it is not possible to specially compare the difference between Naito's results and the results of this study, a reasonable cause may be that the food web used in Naito's study excluded organisms such as seabirds or mammals at high trophic level. Several studies have demonstrated that the TMFs estimated based on food webs only including poikilotherms (fish) are usually lower than those estimated based on food webs including homeotherms (seabirds and mammals) $(14,19,30)$. In addition, no obvious increasing trend was found on the TMFs of nonand mono-ortho PCBs with $\log K_{\text {ow }}$, considering that the regressions of concentration-trophic level for PCBs 77, 81, 126,156 , and 167 are not significant. This was different from those of common PCBs reported by Fisk (14), where TMFs of 26 common PCBs increased from 2.1 to 10.7 as the $\log K_{\text {ow }}$ increased from 5.67 to 7.36 .

As shown in Figure 3c, lipid equivalent concentrations of three non-2,3,7,8-substituted PCDD/F congeners (1,3,6,8TeCDD, 1,3,7,9-TeCDD, and 1,2,7,8-TeCDF) appear to decline significantly with increasing trophic position $(p<0.05)$. Their TMFs were $0.42,0.27$, and 0.39 , respectively, suggesting that these non-2,3,7,8-substituted PCDD/F congeners undergo trophic dilution in the food web. Linear regression analysis 


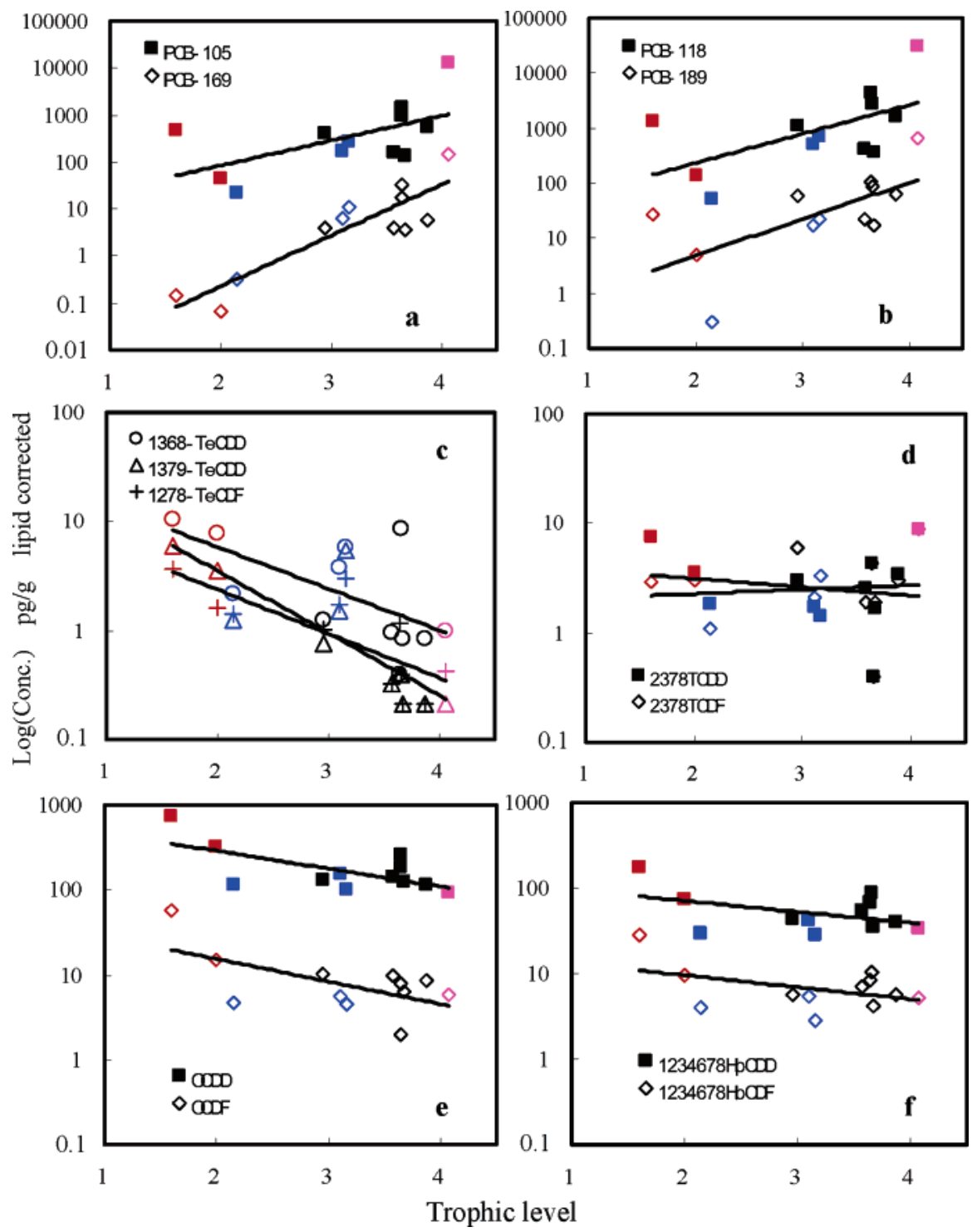

FIGURE 3. Relationship between trophic level of organisms collected in the Bohai Bay and lipid equivalent concentrations of PCDD/F, non- and mono-ortho PCB congeners: (a) 1368-TeCDD, 1379-TeCDD, 1278-TeCDF; (b) 2378-TCDD and 2378-TCDF, (c) 1234678-HpCDD and 1234678-HpCDF; (d) OCDD and OCDF; (e) PCB-105 and PCB-169; (f) PCB-118 and PCB-189. The symbol colors represent different types of organisms: red, primary producers; blue, invertebrates; black, fish; pink, seabird.

showed a flat trend between the trophic levels and lipid equivalent concentrations for 2,3,7,8-TeCDD, 1,2,3,7,8PeCDD, 1,2,3,4,7,8-HxCDD, 2,3,7,8-TeCDF, 1,2,3,7,8-PeCDF, and 2,3,4,7,8-PeCDF, as exemplified by the results for 2,3,7,8TeCDD and 2,3,7,8-TeCDF shown in Figure 3d. Regression analysis showed that the correlations were not statistically significant $(p>0.05)$, and TMFs ranged from $0.82(p=0.406)$ for $1,2,3,4,7,8-\mathrm{HxCDD}$ to 1.22 ( $p=0.577$ ) for $1,2,3,7,8$-PeCDF. These results indicate that low and medium chlorinated 2,3,7,8-substituted PCDD/F congeners do not biomagnify in marine food chains. However, Broman (13) found a statistically significant increasing trend for the total concentration of 2,3,7,8-TCDD, 2,3,4,7,8-PnCDF, and 1,2,3,7,8-PnCDD with trophic level, and the TMF was equal to $1.23(p<0.03)$. And in the investigation of the marine food web in Tokyo Bay (4), a small degree of biomagnification (TMFs 1.02-1.62) was also reported, although this did not appear to be statistically significant. This difference between our data and the values reported by Naito et al. and Broman et al. may be due to the fact that the TMFs calculated by Naito et al. and Broman et al. were based on concentrations which were not corrected by lipids, because the increase of lipid concentration with trophic level accounts in part for the biomagnification of a persistent organic pollutant in a food web $(16,21,31)$.

On the other hand, the lipid equivalent concentrations of the high chlorinated 2,3,7,8-substituted $\mathrm{PCDD} / \mathrm{F}$ congeners (1,2,3,4,6,7,8-HpCDD, OCDD, 1,2,3,4,6,7,8-HpCDF, and OCDF) decreased with an increase in trophic level, as shown in Figure $3 \mathrm{e}$ and $\mathrm{f}$. The correlation was statistically significant for OCDD $(p=0.022)$ and OCDF ( $p=0.047)$, but was not significant for $1,2,3,4,6,7,8-\mathrm{HpCDD}$ and $1,2,3,4,6,7,8-\mathrm{HpCDF}$ ( $p>0.05$ ). TMFs ranged from 0.54 to 0.74 , indicating that high chlorinated 2,3,7,8-substituted $\mathrm{PCDD} / \mathrm{F}$ congeners also undergo trophic dilution in marine food webs, and similar trends were also found by Naito (4) and Broman (13).

Generally, food web magnification is significant for substances with $\log K_{\text {ow }}$ approximately equal to $5-7(13,32)$. In Naito's study (4), it was concluded that the hydrophilicity (water solubility) of a congener is an important determinant governing bioaccumulation of PCDD/Fs, non- and monoortho PCBs in an aquatic environment. To investigate the effects of physicochemical properties on their bioaccumulation in the food web of Bohai Bay, we plotted all the TMFs and their $\log K_{\mathrm{ow}}$ values as shown in Figure 4. While no 
TABLE 2. Slope, $r^{2}$, and $p$ Values of the Plot of Trophic Level versus Logarithmic Concentrations (pg/g Lipid-Corrected) of PCDDs, PCDFs, Non- and Mono-ortho PCBs in Organisms Collected from the Bohai Bay

\begin{tabular}{|c|c|c|c|c|}
\hline congener & slope & $r^{2}$ & TMF & $\mathbf{p}$ \\
\hline $\begin{array}{l}1,3,6,8-T e C D D \\
1,3,7,9-T e C D D \\
2,3,7,8-T e C D D \\
1,2,3,7,8-P e C D D \\
1,2,3,4,7,8-H x C D D \\
1,2,3,4,6,7,8-H p C D D \\
\text { OCDD }\end{array}$ & $\begin{array}{r}-0.38 \\
-0.57 \\
-0.08 \\
0.01 \\
-0.08 \\
-0.13 \\
-0.21\end{array}$ & $\begin{array}{l}0.400 \\
0.682 \\
0.031 \\
0.002 \\
0.070 \\
0.197 \\
0.422\end{array}$ & $\begin{array}{l}0.42 \\
0.27 \\
0.83 \\
1.03 \\
0.82 \\
0.74 \\
0.61\end{array}$ & $\begin{array}{l}0.027^{\circ} \\
0.001^{\circ} \\
0.586 \\
0.962 \\
0.406 \\
0.149 \\
0.022^{\circ}\end{array}$ \\
\hline $\begin{array}{l}1,2,7,8-\mathrm{TeCDF} \\
2,3,7,8-\mathrm{TeCDF} \\
1,2,3,7,8-\mathrm{PeCDF} \\
2,3,4,7,8-\mathrm{PeCDF} \\
1,2,3,4,6,7,8-\mathrm{HpCDF} \\
\text { OCDF }\end{array}$ & $\begin{array}{c}-0.41 \\
0.04 \\
0.09 \\
<0.001 \\
-0.14 \\
-0.27\end{array}$ & $\begin{array}{r}0.561 \\
0.008 \\
0.032 \\
<0.001 \\
0.194 \\
0.360\end{array}$ & $\begin{array}{l}0.39 \\
1.09 \\
1.22 \\
1.01 \\
0.72 \\
0.54\end{array}$ & $\begin{array}{l}0.005 \\
0.789 \\
0.577 \\
0.982 \\
0.152 \\
0.039\end{array}$ \\
\hline $\begin{array}{l}3,3^{\prime}, 4,4^{\prime}-\mathrm{TeCB}(\# 77) \\
3,4,4^{\prime}, 5-\mathrm{TeCB}(\# 81) \\
3,3^{\prime}, 4,4^{\prime}, 5-\mathrm{PeCB}(\# 126) \\
3,3^{\prime}, 4,4^{\prime}, 5,5^{\prime}-\mathrm{H} \times \mathrm{CB}(\# 169) \\
2,3,3^{\prime}, 4,4^{\prime}-\mathrm{PeCB}(\# 105) \\
2,3,4,4^{\prime}, 5-\mathrm{PeCB}(\# 114) \\
2,3^{\prime}, 4^{\prime}, 4^{\prime}, 5-\mathrm{PeCB}(\# 118) \\
2^{\prime}, 3^{\prime}, 4,4^{\prime}, 5-\mathrm{PeCB}(\# 123) \\
2,3,3^{\prime}, 4,4^{\prime}, 5-\mathrm{H} \times \mathrm{CB}(\# 156) \\
2,3,3^{\prime}, 4,4^{\prime}, 5^{\prime}-\mathrm{H} \times \mathrm{CB}(\# 157) \\
2,3^{\prime}, 4,4^{\prime}, 5,5^{\prime}-\mathrm{H} \mathrm{CB}(\# 167) \\
2,3,3^{\prime}, 4,4^{\prime}, 5,5^{\prime}-\mathrm{HpCB}(\# 189)\end{array}$ & $\begin{array}{l}0.35 \\
0.22 \\
0.64 \\
1.09 \\
0.53 \\
0.97 \\
0.53 \\
0.85 \\
0.55 \\
0.57 \\
0.53 \\
0.67\end{array}$ & $\begin{array}{l}0.192 \\
0.076 \\
0.210 \\
0.798 \\
0.350 \\
0.487 \\
0.349 \\
0.420 \\
0.300 \\
0.403 \\
0.300 \\
0.432\end{array}$ & $\begin{array}{r}2.26 \\
1.66 \\
4.34 \\
12.26 \\
3.40 \\
9.29 \\
3.40 \\
7.10 \\
3.55 \\
3.70 \\
3.37 \\
4.64\end{array}$ & $\begin{array}{r}0.154 \\
0.386 \\
0.134 \\
<0.001 \\
0.043 \\
0.012 \\
0.043 \\
0.023 \\
0.066 \\
0.027 \\
0.065 \\
0.02^{a}\end{array}$ \\
\hline
\end{tabular}

${ }^{a}$ The indicated $p$ values represent statistically significant increases or decreases of the lipid equivalent concentration (i.e., $<0.05$ ) b $1,2,3,6,7,8-\mathrm{HxCDD}, 1,2,3,7,8,9-\mathrm{HxCDD}, 1,2,3,4,7,8-\mathrm{HxCDF}, 1,2,3,6,7,8-$ $\mathrm{HxCDF}, 1,2,3,7,8,9-\mathrm{HxCDF}, 2,3,4,6,7,8-\mathrm{HxCDF}$, and $1,2,3,4,7,8,9-\mathrm{HpCDF}$ are not included in the table because these congeners were under the detection limit in most of the samples and were not sufficient for calculation.

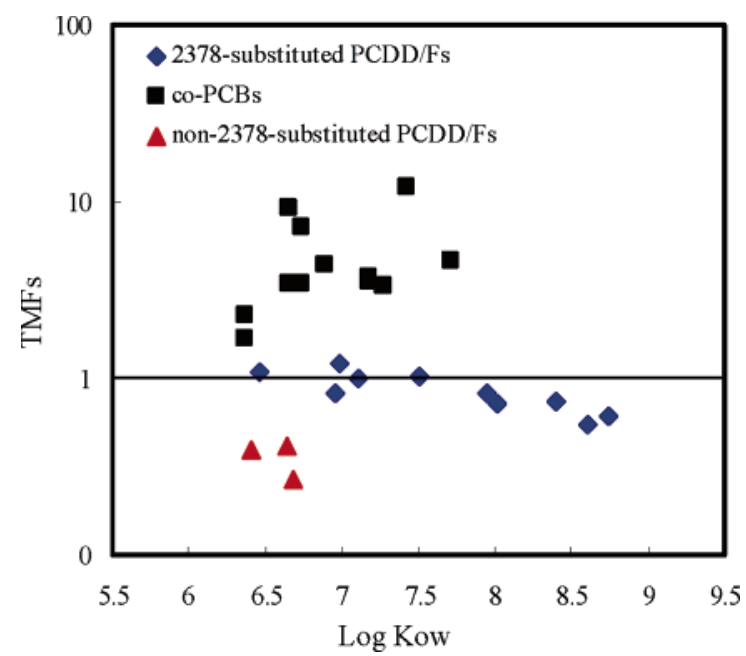

FIGURE 4. Relationship between food web magnification factors (TMFs) and log $K_{0 w}$ of PCDD, PCDF, non- and mono-ortho PCB congeners in the Bohai Bay marine food web. $\log K_{\text {ow }}$ values were derived based on Govers and Krop (39) for PCDD/Fs and Hawker and Connell (40) for non- and mono-ortho PCBs.

relationships between the TMFs and log $K_{\text {ow }}$ values were found, the TMFs of non- and mono-ortho PCBs are greatly higher than those of PCDD/Fs. In addition, the TMFs for non-2,3,7,8-substitued PCDD/Fs are lower than those of 2,3,7,8-substituted PCDD/Fs with similar $\log K_{\text {ow. }}$. This could be explained by the fact that the metabolic transformation rate dominates the overall depuration rate of dioxin, and the metabolic transformation rate is higher for PCDD/Fs than for non- and mono-ortho PCBs, on the basis of the fact that gill elimination, respiration uptake, and dietary uptake rates are all dependent on the $\log K_{\text {ow }}(17,33,34)$. This corresponds well with the studies by Opperhuizen and Sijm (35), which reported that some 2,3,7,8-unsubstituted congeners are taken up at a normal rate and eliminated rapidly due to biotransformation and enzymatic oxidation, and 2,3,7,8-TeCDD-like congeners are taken up and eliminated at constant rate. Furthermore, the different metabolic transformation rates for between PCDD/Fs and for non- and mono-ortho PCBs can also be supported by the relative lower half-lives of PCDD/Fs (18-57 days) compared with those of non- and mono-ortho PCBs (28-107 days, ref 36-38).

\section{Acknowledgments}

We thank Shigeki Masunaga (Graduate School of Environment and Information Sciences, Yokohama National University) for his helpful comments on an earlier version of the manuscript. Financial support by the State High Tech. Development Project [2001AA646010-5], the Japanese International Cooperation Agency, and the National Natural Science Foundation of China [40021101] is gratefully acknowledged.

\section{Supporting Information Available}

Experimental details and table of relative contributions of PCDDs, PCDFs, and non- and mono-ortho PCBs to TEQs in organisms collected in Bohai Bay (pdf). This material is available free of charge via the Internet at http:/ / pubs.acs.org.

\section{Literature Cited}

(1) Senthil Kumar, K.; Kannan, K.; Paramasivan, O. N.; Shanmuga Sundaram, V. P.; Nakanishi, J.; Masunaga, S. Polychlorinated dibenzo- $p$-dioxins, dibenzofurans, and polychlorinated biphenyls in human tissues, meat, fish, and wildlife samples from India. Environ. Sci. Technol. 2001, 35, 3448-3455.

(2) Kim, H. K. Origin of dioxins in drinking water and the effect of water treatment for the minimization of dioxins. Ph.D. Thesis, Graduate School of Engineering Hokkaido University, Japan, DC, 2002.

(3) Kjeller, L. O.; Rappe, C. Time trends in levels, patterns, and profiles for polychlorinated dibenzo- $p$-dioxins, dibenzofurans, and biphenyls in a sediment core from Baltic proper. Environ. Sci. Technol. 1995, 29, 346-355.

(4) Naito, W.; Jin, J.; Kang, Y. S.; Yamamuro, M.; Masunaga, S.; Nakanishi, J. Dynamics of PCDD/DFs and coplanar-PCBs in an aquatic food chain of Tokyo Bay. Chemosphere 2003, 53, 347362.

(5) Wu, W. Z.; Schramm, K. W.; Kettrup, A. Bioaccumulation of polychlorinated dibenzo- $p$-dioxins and dibenzofurans in the foodweb of Ya-Er lake area, China. Water Res. 2001, 35 (5), 11411148.

(6) Braune, B. M.; Simon, M. Dioxins, furans, and non-ortho PCBs in Canadian Arctic seabirds. Environ. Sci. Technol. 2003, 37, 3071-3077.

(7) Bayarri, S.; Baldassarri, L. T.; Iacovella, N.; Ferrara, F.; Domenico, A. D. PCDDs, PCDFs, PCBs and DDE in edible marine species from the Adriatic Sea. Chemosphere 2001, 43, 601-610.

(8) Corsolini, S.; Kannan, K.; Imagawa, T.; Focardi, S.; Giesy, J. P. Polychloronaphthalenes and other dioxin-like compounds in Arctic and Antarctic marine food webs. Environ. Sci. Technol. 2002, 36, 3490-3496.

(9) Jimenez, B.; Gonzalez, M. J.; Jimenez, O.; Reich, S.; Eljarrat, E.; Rivera, J. Evaluation of 2,3,7,8 specific congener and toxic potency persistent polychlorinated dibenzo- $p$-dioxins and polychlorinated dibenzofurans in cetaceans from the Mediterranean Sea, Italy. Environ. Sci. Technol. 2000, 34, 756-763.

(10) Kannan, K.; Hilscherova, K.; Imagawa, T.; Yamashita, N.; Williams, L. L.; Giesy, J. P. Polychorinated naphthalenes, -biphenyls, -dibenzo-p-dioxins, and -dibenzofurans in doublecrested cormorants and herring gulls from Michigan Waters of the Great Lakes. Envrion. Sci. Technol. 2001, 35, 441-447.

(11) Tanabe, S.; Watanabe, M.; Minh, T. B.; Kunisue, T.; Nakanishi, S.; Ono, H.; Tanaka, H. PCDDs, PCDFs, and coplanar PCBs in albatross from the North Pacific and Southern Oceans: levels, patterns and toxicological implications. Envrion. Sci. Technol. 2004, 38, 403-413. 
(12) Iwata, H.; Watanabe, M.; Okajima, Y.; Tanabe, S.; Amano, M.; Miyazaki, N.; Petrov, E. A. Toxicokinetics of PCDD, PCDF, and coplanar PCB congeners in Baikal seals, Pusa sibirica: agerelated accumulation, maternal transfer, and hepatic sequestration. Envrion. Sci. Technol. 2004, 38, 3505-3513.

(13) Broman, D.; Näf, C.; Rolff, C.; Zebühr, Y.; Fry, B.; Hobbie, J. Using ratios of stable nitrogen isotopes to estimate bioaccumulation and flux of polychlorinated dibenzo- $p$-dixoins (PCDDs) and dibenzofurans (PCDFs) in two food chains from the Northern Baltic. Environ. Toxicol. Chem./SETAC 1992, 11, 331345.

(14) Fisk, A. T.; Hoboson, K. A.; Norstrom, R. J. Influence of chemical and biological factors on trophic transfer of persistent organic pollutants in the Northwater Ploynya marine food web. Environ. Sci. Technol. 2001, 35, 732-738.

(15) Ruus, A.; Ugland, K. I.; Espeland, O.; Skaare, J. U. Organochlorine contaminants in a local marine food chain from Jarfjord, Northern Norway. Mar. Environ. Res. 1999, 48, 131-146.

(16) Kidd, K. A.; Schindler, D. W.; Hesslein, R. H.; Muir, D. C. G. Correlation between stable nitrogen isotope ratios and concentrations of organochlorines in biota from a freshwater food web. Sci. Total Environ. 1995, 160/161, 381-390.

(17) Ruus, A.; Ugland, K. I.; Skaare, J. U. Influence of position on organochlorine concentrations and compositional patterns in a marine food web. Environ. Toxicol. Chem./SETAC 2002, 21 (11), 2356-2364.

(18) Muir, D.; Savinova, T.; Savinov, V.; Alexeeva, L.; Potelov, V.; Svetochev, V. Bioaccumulation of PCBs and chlorinated pesticides in seals fishes and invertebrates from the White Sea, Russia. Sci. Total Environ. 2003, 306, 111-131.

(19) Hop, H.; Borga, K.; Gabrielsen, G. W.; Kleivane, L.; Skaare, J. U. Food web magnification of persistent organic pollutants in poikilotherms and homeotherms from the Barents Sea. Environ. Sci. Technol. 2002, 36, 2589-2597.

(20) Hoekstra, P. F.; O’Hara, T. M.; Fisk, A. T.; Boregå, K.; Solomon, K. R.; Muir, D. C. G. Trophic transfer of persistent organochlorine contaminants (OCs) within an Arctic marine food web from the southern Beaufort-Chukchi Seas. Environ. Pollut. 2003, 124, 509-522.

(21) Rasmussen, J. B.; Rowan, D. J.; Lean, D. R. S.; Carey, J. H. Food chain structure in Ontario lakes determines PCB levels in lake trout (Salvelinus namaycush) and other pelagic fish. Can. J. Fish. Aquat. Sci. 1990, 2030-2038.

(22) The Provisional Manual of Aquatic Life Research about Dioxins. Water Quality Management, Division of Water Quality Preservation Bureau; Environmental Agency of Japan: Tokyo, 1998.

(23) Su, Q. L.; Tang, Q. S. Study on ecosystem dynamics in coastal ocean II Processes of the Bohai Sea ecosystem dynamics (in Chinese); Science Press: Beijing, 2002; pp 216-217.

(24) Sakurai, T.; Kim, J. G.; Suzuki, N.; Nakanishi, J. Polychlorinated dibenzo- $p$-dioxins and dibenzofurans in sediment, soil, fish and shrimp from a Japanese freshwater lake area. Chemosphere 1996, 33 (10), 2007-2020.

(25) Hu, J. Y.; Wan, Y.; Shao, B.; Jin, X. H.; An, W.; Jin, F.; Yang, M.; Wang, X. J.; Sugisaki, G. Occurrence of trace organic contaminants in Bohai Bay and its adjacent Nanpaiwu River, North China. Mar. Chem. 2005, in press.

(26) Kumar, K. S.; Kannan, K.; Corsolini, S.; Evans, T.; Giesy, J. P.; Nakanishi, J.; Masunaga, S. Polychlorinated dibenzo- $p$-dioxins, dibenzofurans, and polychlorinated biphenyls in polar bear, penguin and south polar skua. Environ. Pollut. 2002, 119, 151161.

(27) Van den Berg, M.; Birnbaum, L.; Bosveld, A. T. C.; Vrunström, B.; Cook, P.; Feeley, M.; Giesy, J. P.; Hanberg, A.; Hasegawa, R.; Kennedy, S. W.; Kubiak, T.; Larsen, J. C.; Rolaf van Leeuwen, F.
X.; Djien Liem, A. K.; Nolt, C.; Peterson, R. E.; Poellinger, L.; Safe, S.; Schrenk, D.; Tillitt, D.; Tysklind, M.; Younes, M.; Waern F.; Zacharewski, T. Toxic equivalency factors (TEFs) for PCBs, PCDDs, PCDFs for humans and wildlife. Environ. Health Persp. 1998, 106, 775-792.

(28) Bordajandi, L. R.; Gümez, G.; Fernández, M. A.; Abad, E.; Rivera, J.; González, M. J. Study on PCBs, PCDD/Fs, organochlorine pesticides, heavy metals and arsenic content in freshwater fish species from the River Turia (Spain). Chemosphere 2003, 53, $163-167$.

(29) Kumar, K. S.; Bowerman, W. W.; De Vault, T. L.; Takasuga, T.; Rhodes Jr, O. E.; Brisbin, I. L., Jr.; Masunaga, S. Chlorinated hydrocarbon contaminants in blood of black and turkey vultures from Savannah River Site, South Carolina, USA. Chemosphere 2003, 53, 173-182.

(30) Braune, B. M.; Norstrom, R. J. Dynamics of organochlorine compounds in herring gull: III. Tissue distribution and bioaccumulation in Lake Ontario gulls. Environ. Toxicol. Chem./ SETAC 1989, 8, 957-968.

(31) Kidd, K. A.; Hesslein, R. H.; Ross, B. J.; Koczanski, K.; Stephens, G. R.; Muir, D. C. G. Bioaccumulation of organochlorines through a remote freshwater food web in the Canadian Arctic. Environ. Pollut. 1998, 102, 91-103.

(32) Thomann, R. V. Bioaccumulation model of organic chemical distribution in aquatic food chains. Environ. Sci. Technol. 1989 23, 699-707.

(33) Mackintosh, C. E.; Maldonado, J.; Hongwu, J.; Hoover, N.; Chong, A.; Ikonomou, M. G.; Gobas, F. A. P. C. Distribute of phthalate esters in a marine aquatic food web: comparison to polychlorinated bipheyls. Environ. Sci. Technol. 2004, 38, 20112020.

(34) Mackay, D.; Fraser, A. Bioaccumulation of persistent organic chemicals: mechanisms and models.Environ. Pollut. 2000, 110, 375-391.

(35) Opperhuizen, A.; Sijm, D. T. H. M. Bioaccumulation and biotransformation of polychlorinated dibenzo- $p$-dioxins and dibenzofurans in fish. Environ. Toxicol. Chem./SETAC 1990, 9, 175-186.

(36) Hektoen, H.; Berge, J. A.; Ingebrigtsen, K.; Knutsen, J.; Oehme, M. Elimination of polychlorinated dibenzofurans and dibenzop-dioxins from blue mussel (Mytilus edulis) and tissue distribution of 2,3,7,8-tetrachlorodibenzo- $p$-dioxin (2,3,7,8-TCDD). Chemosphere 1994, 29, 1491-1499.

(37) Fisk, A. T.; Norstrom, R. J.; Cymbalisty, C. D.; Muir, D. C. G. Dietary accumulation and depuration of hydrophobic organochlorines: bioaccumulation parameters and their relationship with the octanol/water partition coefficient. Environ. Toxicol. Chem./SETAC 1998, 17, 951-961.

(38) Gardinali, P. R.; Sericano, J. S.; Wade, T. L. Uptake and depuration of toxic halogenated aromatic hydrocarbons by the American oyster (Crassostrea virginica): a field study. Chemosphere 2004, 54, 61-70.

(39) Govers, H. A. J.; Krop, H. B. Partition constants of chlorinated dibenzofurans and dibenzo- $p$-dioxins. Chemosphere 1998, 37 (9-12), 2139-2152.

(40) Hawker, D. W.; Connell, D. W. Octanol-water partition coefficients of polychlorinated biphenyl congeners. Environ. Sci. Technol. 1988, 22, 382-387.

Received for review August 26, 2004. Revised manuscript received January 18, 2005. Accepted January 25, 2005.

ES048657Y 